\title{
Strategies and Practices of College Physical Education Curriculum Teaching based on Core Literacy
}

\author{
Xudong Wang ${ }^{1, *}$, Yuqin Zhang ${ }^{2}$ \\ ${ }^{1}$ Sports Department, Shaanxi University of Chinese Medicine,Xian yang, Shaanxi, China \\ ${ }^{2}$ Student, Shaanxi University of Chinese Medicine, Xian yang, Shaanxi, China \\ *Corresponding author.Email:790086212@qq.com2934874624@qq.com
}

\begin{abstract}
The lack of the dimension of core physical education quality is an important factor leading to the decline of the quality of college students' physical education courses. Various countries formulate corresponding measures and policies for the reform and implementation of core physical education quality. This paper aims to analyze the influence of college physical education curriculum teaching under the core literacy on teachers and students through the analysis of existing literature and field understanding, so as to carry out some planning and practice for the subsequent strategy formulation and teaching implementation. The teaching strategy and practice of college physical education course are insufficient because the students' core accomplishment of physical education is relatively weak, the professional degree of various sports skills is low, and they lack the awareness of physical health. The method is to enhance teachers' and students' ideology, practice and improve their own ability.
\end{abstract}

Keywords: College physical education, Core literacy, Strategy and Practice

\section{INTRODUCTION}

Core quality of physical education is mainly composed of sports skills, healthy behavior and sports morality, which mainly reflects the excellent quality and ability of physical education and health discipline. It aims to cultivate students' interest in sports and improve their physical quality through healthy and reasonable methods, so that college students can adapt to social life and work as soon as possible. With the popularization of college education ${ }^{[1],}$ undergraduate degree has become more and more common, and enterprises have more choices in talent selection, and the requirements for college students have gradually improved. Therefore, many graduates now hit a wall in their jobs due to their own physical reasons or various reasons in the process of getting along with colleagues. It shows the importance of physical education and the necessity of sports reform.

\section{CURRENT SITUATION OF PHYSICAL EDUCATION IN UNIVERSITIES}

\subsection{The current situation of low physical education quality among college students}

With the popularization of college education, the problem of low health quality of college students is gradually exposed ${ }^{[2]}$. According to the first monitoring report of the "National Student physical health monitoring Network" of the Ministry of Education in 2002, the height and weight of Chinese students showed an increasing trend, while the vital capacity decreased obviously. In following years, the investigation and research reports showed that although the physical health of Chinese students had been effectively improved, the speed, explosive force and endurance showed a downward trend. And with the popularization of electronic products, the detection rate of students' poor eyesight is also high. Most candidates are restricted when applying for major due to physical ineligibility or health problems.

The serious decline in the body quality of most students is due to the traditional classroom teaching focusing on imparting skills, the low participation of student, and the physical education system of "valuing culture while ignoring military" in high school ${ }^{[3]}$. These reasons lead to students' lack of effective extracurricular physical exercise and related consciousness, resulting in the serious decline of students' fitness. Despite learning professional skills, they are not able to implement them. Therefore, through the effective reform of physical 
education teaching in colleges and universities, it is urgent to make students participate in physical exercise better and improve their physical quality.

\subsection{The importance of physical education in colleges and universities}

"Developing sports and improving people's physical fitness" is an important national policy put forward by Comrade MAO Zedong. The support for physical education can be seen from the policies of several national leaders since then. This shows the importance of sports. Physical education in colleges and universities is the most important link to improve people's physical quality, and the people's body is the foundation of national development. The physical quality of college students can be effectively improved only by implementing the training of students' physical quality in physical education and standardizing physical education with the explicit guiding policy of core quality $^{[4]}$.

\section{THE APPLICATION OF CORE LITERACY IN PHYSICAL EDUCATION TEACHING}

"Core literacy", as a guiding plan clearly proposed by the Party, has a clear guiding significance for the PE reform in colleges and universities. The PE reform in colleges and universities is inseparable from the normative role of "core literacy".

\subsection{The relationship between core literacy and PE teaching}

In 2017, the 18th National Congress put forward the new concept of "core literacy" for the first time. According to the requirements for the physical quality and related aspects of new youth, taking core literacy as the core guiding ideology to guide the reform of physical education in colleges and universities has become the key to improve the requirements of college students in all aspects ${ }^{[5]}$, and cultivate students' ability and literacy to adapt to their own lifelong development and social development. In addition, the proposal of "core literacy" will have a great impact on the existing physical education, force teachers to change the existing conservative ideas and actively absorb new ideas. At the same time, students are forced to face up to physical education actively or passively, contact and understand physical education, and then love physical education and take physical education as a part of life to meet the social needs as soon as possible, as shown in figure 1 .

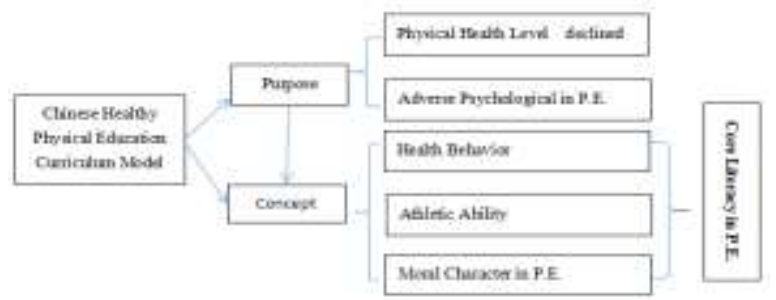

Figure 1. College students physical health curriculum model concept diagram under core literacy

As shown In figure 1, the purpose of health at the university of physical education curriculum model is better in the service of physical health, physical education curriculum in the student activities and learning performance by the adverse psychological factors. More important is the idea of health behavior, athletic ability and physical character of three important aspects, to solve the problem of the construction of the university sports curriculum development and strategy research, Give full play to the leading role of teachers and students' learning initiative, adjust the target in time, help students learn how to exercise, stimulate the love of sports, so as to promote the development of students' overall physical quality and health.

Physical education is one of the longest courses in school teaching ${ }^{[6]}$, but due to the long-term neglect of schools and parents, the development of physical education is not optimistic. However, under the current situation that society pays more and more attention to students' own physical quality when selecting college talents, college physical education has been put back to an unprecedented height, and the old teaching system does not adapt to the requirements of the new society, which leads to the urgent implementation of the reform of college physical education.

\subsection{The influence of the application of core literacy in PE on college students}

For college students themselves, the long-term lack of attention to sports leads to the decline of physical quality and the lack of interest in sports activities, which may lead to maladjustment after entering the society, so it needs to be made up as soon as possible. The application of core literacy in sports can promote students to cultivate healthy behavior, mainly including optimism and openness, love life, good communication and so on. These behaviors can effectively make students grow up in an all-round way, develop healthily and base themselves on the society. The cultivation of students' core literacy can not only strengthen students' autonomous learning habits, but also exercise students' physical and psychological quality, which is conducive to the improvement of College Students' self-living standards.

For the student group, because many sports can only be completed with the cooperation of students, the 
guidance of PE teachers in this link can cultivate students' spirit of unity and cooperation and improve students' sense of responsibility and honor. At the same time, teachers can carry out the penetration education of core literacy in the process of educating students. The application of core literacy in college physical education courses can cultivate students' ability to adapt to the environment and communicate with others, and enhance students' ability to integrate with society after graduation. In the context of core literacy, in the process of forming core literacy, students can not only meet the height of social requirements, but also meet the needs of themselves, so that they can more calmly face the communication and work with colleagues after graduation.

\section{THE INFLUENCE AND PROMOTION OF CORE LITERACY ON COLLEGE PE TEACHING}

Under the influence of core literacy, colleges and universities should require PE teachers to effectively implement the teaching plan, give full play to the guiding role, and actively and effectively lead students to learn and master PE knowledge. At the same time, PE teachers in colleges and universities should update their teaching concepts, improve their educational cognition and teaching methods in combination with the reality. $\mathrm{PE}$ teachers in colleges and universities as a guider of physical exercise to college students, should strive to absorb the advanced knowledge, improve their teaching level, create a good learning atmosphere for students, encourage students to learn to think independently, enables students to learn relevant knowledge more easily, so as to better develop college students' core literacy.

Under the practice of core literacy, colleges and universities are bound to increase investment in physical education, strengthen the construction of teaching staff, and provide a strong guarantee for the development of college students' core literacy. In this case, the competition among college PE teachers is bound to intensify, which can promote college PE teachers to actively improve their own ability.

Under the circumstance that the core literacy is highly respected by schools and the overall physical health of college students is not satisfactory ${ }^{[7]}$, it is particularly important to cultivate the feelings of college students towards sports by using core literacy. The core of cultivating college students' quality requires teachers to constantly infiltrate in the teaching process, carefully design teaching contents and methods elaborate, increase the interest of physical education, let students master knowledge and skills in a happy atmosphere to, enable students to complete the training more quickly, improve the efficiency of sports teaching. At the same time, it is also required to cultivate students' spirit of unity and cooperation, enhance students' sense of responsibility and collective honor, cultivate students' interest in sports, so as to improve their enthusiasm for sports and form good habits of physical exercise.

\section{SUGGESTIONS ON PE TEACHING REFORM BASED ON CORE LITERACY}

\subsection{Improve teachers' standards}

During the implementation of college PE curriculum, teachers should always learn advanced knowledge to enrich themselves ${ }^{[8]}$. In their spare time, they should enrich themselves through the Internet, library and other channel, update their ideas do keep pace with the times, enrich teaching methods, improve their comprehensive quality, so as to adapt to the new ideas of students. Combined with the specific situations of the students, different teaching methods are given from the point of view of core literacy to cultivate students' psychological quality, so that students can consciously join in sports and obtain the latest ideas. Not only that, college sports teachers should also combine students' daily habits on the basis of abundant teaching methods, enable students to transform the knowledge learned in class into daily knowledge, improve the use frequency, take sports as a part of life, and take scientific exercise and training as their own interests, so that the students cannot lag behind the social development with strengthening themselves.

\subsection{Relevant leaders should give corresponding attention}

The implementation of the reform needs the support of human and material resources ${ }^{[9]}$. On this basis, relevant measures should be formulated and implemented to promote the reform based on the idea of student-centered education, so as to change the single teaching method in the past and combine with the new education system to enrich the teaching means. As an important part of college physical education reform, relevant leaders should pay attention to grasp and control the reform direction to ensure the implementation of the reform. On this basis, they should give full play to their personality charm and strong influence, take the lead in implementing the reform plan, so as to accelerate the implementation of the strategy. At the same time, relevant leaders should also supervise the PE teachers to implement the reform curriculum in place so that students can really be trained.

\subsection{Pay attention to the reform of teaching methods}

When facing young people, teachers should go deep into the student group to understand students' learning 
tendency, change some inherent thinking in time, put forward targeted teaching plans according to students' specific physical quality, and improve students' learning interest through flexible teaching methods and communication tools, so that students can consciously participate in PE Learning activities, love sports more and cultivate sports loving projects. At the same time, teachers should help students establish basic sports concepts, make students maintain a positive and optimistic attitude towards sports, and master basic sports methods and skills, so as to become talents who meet social needs and have strong physique and sound personality.

\subsection{Vigorously promote the holding of school sports events}

The cultivation of sports morality and the examination of sports teaching cannot be separated from the promotion and restriction of sports events. Through the study of physical education courses, students can stimulate their enthusiasm for sports and improve their physical quality. The holding of sports events can cultivate students' competitive spirit and tenacious will, help students establish the awareness of abiding by discipline and law, and improve students' sense of responsibility and collective honor under the constraints of the rules of the event.

\subsection{Actively publicize and strive to improve the students' acceptance}

Schools shall promote the benefits and requirements of sports to student groups through various activities, encourage students to get rid of the traditional concept of judging high and low by achievements, gradually make students realize the importance of sports, and then actively accept the objectives and tasks of the new teaching reform and tasks. These enables students to participate in the teaching process with a high degree of enthusiasm and consciousness, overcome all kinds of difficulties and negative emotions in study and life independently, improve their ability to adapt to campus and social environment, and improve students' learning awareness.

\section{CONCLUSION}

The lack of the dimension of core physical education quality is an important factor leading to the decline of the quality of college students' physical education courses. Various countries formulate corresponding measures and policies for the reform and implementation of core physical education quality. To sum up, the PE reform based on core literacy has a certain impact on both university teachers and students. and university teachers should strive to absorb and apply core literacy to improve teaching methods and strive to do a good job in college PE curriculum reform. College students should cultivate their sports habits and hobbies at the time of PE curriculum reform. At the time of college physical education curriculum reform, all parties should take their respective duties on the basis of core quality, observe carefully and summarize actively in the implementation of reform teaching, so as to make contributions to college physical education curriculum reform and the cultivation of talents with high overall quality. The teaching strategy and practice of college physical education course are insufficient because the students' core accomplishment of physical education is relatively weak, the professional degree of various sports skills is low, and they lack the awareness of physical health. The method is to enhance teachers' and students' ideology, practice and improve their own ability.

\section{REFERENCES}

[1] Liu Yadong. Practical approaches and strategies of college PHYSICAL education reform based on core literacy $[\mathrm{J}]$. Modern Vocational Education, 2018, 000(011):144.

[2] Ji Wei. Research on the Implementation of PHYSICAL Education and Health Curriculum based on the Discipline Core Literacy [D]. Northwest University for Nationalities, 2020.

[3] Wan Xidong. Practice and exploration of problem leading and probing strategies based on core literacy in PHYSICAL Education [J]. Reading, Writing and Calculating (teacher edition): Quality Education Forum, 2016(48):130-130.

[4] Hong, X. (2018). Effective Teaching Strategies and research of PHYSICAL Education Classroom based on core discipline Literacy. Modern Sports Technology, 008(010), 85-86.

[5] Ma Yu. Research on construction of Martial Arts Curriculum System in Colleges and Universities based on Core Sports Literacy. Northeast Petroleum University.

[6] Ren Zhendong. Discussion on college PHYSICAL Education Curriculum teaching based on core literacy $[\mathrm{J}]$. Stationery \& Technology, 2018, 000(023):162-163.

[7] Ji Wei. Research on the Implementation of PHYSICAL Education and Health Curriculum based on the Discipline Core Literacy [D]. Northwest University for Nationalities, 2020.

[8] Kong Chong, Ping Jie. [C]// Proceedings of the 11th National Sports Science Conference. 2019.

[9] Qiu Feng. Construction and Practice of Curriculum System of Physical Education Major (Junior College) based on the Goal of Core Literacy Cultivation -- Taking Heyuan Vocational And Technical College as an example [J]. Contemporary Educational Practice and Teaching Research, 2017(11):33-34. 